\title{
Understanding Attitude Towards Reusable Bag: Its Antecedents and Consequences
}

\author{
Ayu Ekasari ${ }^{1}$, Fatik Rahayu², Afif Diamanta ${ }^{3}$ \\ 1,2,3 University of Trisakti, Jakarta, Indonesia \\ E mail: ayu.ekasari@trisakti.ac.id
}

\begin{abstract}
Environmental damage caused by individual's and household activities has increased the need to foster people to act pro-environmentally. Indonesia is an emerging country that has committed to encourage people to use reusable bag that can help reducing plastic waste and preserve the environment. However, people's willingness to use reusable bag is far from being expected. This research aims to examine the internal and external factors as well as consequences of attitude towards using reusable bag. The questionnaire survey was administered to 300 respondents that have ever seen and understood the usability of reusable bag. Structural equation modelling was then used to analyse the data. The findings reveal that environmental knowledge, lifestyle of health and sustainability as well as moral norms do influence attitude towards reusable bag which leads to intention to use it, which is consistent with some previous studies. The study also finds that people's attitude is not influenced by social influence from others. Managerial implications are given to the policy maker and retailers to promote reusable bag. To the best of the authors' knowledge, no study has been conducted to integrate the external and internal factors of attitudes towards reusable bag and predicts the intention to use it. Future studies needs to test the model to other pro environmental behaviour and to conduct a cross-cultural study regarding it.
\end{abstract}

Keywords: Environmental Knowledge, Social Influence, Lifestyle of Health and Sustainability, Moral Norm, Attitude towards Reusable Bag, Behavioural Intention.

\section{A. INTRODUCTION}

As the second largest producer of plastic waste in the world (Jambeck et al., 2015), Indonesia should work hard to resolve this problem . Shopping bags made of plastic contribute to plastic waste. In 2014, the Ministry of Environment and Forestry sparked the idea of "Indonesia Free of Waste in 2020". One of the efforts made by the Ministry of Environment and Forestry was a campaign to limit the use of plastic shopping bags and encourage consumers to bring their own shopping bags. The paid plastic bag policy was launched in 17 cities as a pilot project in 2016 and it was supported by Indonesian Retailer Association. However, the campaign was not continued. Although nowadays retailers sell reusable bag and charge for the plastic bags, many people still use plastic bags especially in traditional market. The use of reusable bag is a new phenomenon in Indonesia, and consumers need to be educated about it.

On the other hand, the concept of sustainable development that has been accommodated by the Government of Republic of Indonesia urges people to preserve the environment for the benefits of future generations. Switching to reusable bag is part of sustainable consumptions that leads to sustainable development. Sustainable consumption refers to holistic approach to reduce negative environmental impacts of 
peoples' consumption by promoting a shift of consumption patterns while improving the quality of life (Akenji et al., 2015). The concept of sustainable consumption has become the global political agenda of many countries and is part of the SDG goals (Nation, 2017). However, it is not easy to change people's behaviour and it needs ongoing campaign to inform people about the environmental damage caused by plastics and urge them to switch to reusable bag. The use of reusable bags can also be interpreted as environmentally caring behavior that is interpreted as the purchase, use and disposal of personal and household products that do not harm the environment (Stern, 2000).

In order to achieve sustainable consumption, marketing discipline can contribute through social marketing, namely the use of marketing principles that allow individuals in the community to initiate and implement ideas and actions that can change society for the better (Saunders et al., 2015) This definition does not leave the initial thinking of social marketing, namely changing people's behavior by using conventional marketing techniques. Saunders et al., (2015), expanded the definition by incorporating the concept of community transformation into a better life through the application of ideas and actions that brings benefit to the community. This is in accordance with the campaign to use reusable bags that ultimately make people's lives more healthier because the environment is saved from plastic bag waste. Peattie \& Peattie (2009) also suggested the use of social marketing concepts to campaign for a reduction in the consumption of products/services that are not useful or harmful to the environment and health.

From the theoretical perspective, Geller (1989) and McKenzie-Mohr (2000) came up with the idea of using an attitudinal approach in designing social marketing campaign to change people's behavior to be more sustainable.. Both researchers stated that policymakers need to understand the psychological aspects of the target audience (in this case society) before designing a message to change people's behavior. By delivering the right message, it is expected that society will have positive attitude regarding the campaigned issues.

As one of the original constructs of Theory of Planned Behavior, attitude represents individual's feeling of favor/disfavor toward a given object or to perform a certain behavior (Ajzen, 1991). Attiude has been widely used to predict the intention of applying sustainable consumption such as driving eco-friendly cars (Martin \& Väistö, 2016), clothing from organic materials (H. J. Chang \& Watchravesringkan, 2018), food (Teng \& Wang, 2015), green hotel (Han et al., 2020), energy-efficient homewares (Hameed et al., 2019), eco-friendly cosmetics (Singhal \& Malik, 2018) as well as eco-friendly bag (S. H. Chang \& Chou, 2018).

However, relatively few efforts have been made to integrate the factors that form attitude towards pro-environmental behavior. This research proposes a model that combining several antecedents of attitude towards reusable bag such as social influence (Varshneya et al., 2017) and environmental knowledge (Fawehinmi et al., 2020) that represents the external influences as well as moral norm (Liu et al., 2020) and Lifestyle of Health and Sustainability (Matharu et al., 2021) that represent the 
internalization of a person is looking at an object. It is suspected that both external and internal factors affect a person's intentions to engage in pro-environmental behavior. Furthermore, the proposed model also includes the consequences of attitude, namely behavioural intention.

By understanding the factors that can form a positive attitude towards the use of reusable bags, policymakers or retailers can design the right marketing communication strategy in order to target the target audience (consumers) and encourage them to use reusable bags.

\section{B. LITERATURE REVIEW AND HYPOTHESIS DEVELOPMENT}

In making purchasing decisions, individuals are influenced a lot by others and to some degree, this social influence is quite large especially when it comes from a figure who is considered important/respected. Social influence can occur when a person changes his behaviour, thoughts and feelings to conform to social norms (Chen-Yu \& Seock, 2002). An experiment conducted by Wei et al. (2019) proved that people tend to be influenced by others they trust and are willing to conform to their opinions. Regarding the influence of social influence on environmentally caring behaviour, some studies prove that in deciding to behave environmentally, a person is heavily influenced by the people around him (Costa et al., 2014; Salazar et al., 2013; Varshneya et al., 2017).

$\mathrm{H1}$ : there is a positive influence of social influence on attitude towards reusable bag.

In consuming green products or conducting environmentally caring behaviours, one needs information that can increase his knowledge about the benefits of environmentally caring behaviour. Information about this environment can improve positive attitudes towards environmentally caring behaviour. By Burchett (2015), environmental knowledge is defined as awareness of human interaction, environmental issues and matters related to ecological systems. Knowledge of the environment will encourage people to do things that could prevent environmental damage (Fawehinmi et al., 2020; Levy \& Marans, 2012).

Hypothesis 2: there is a positive influence of environmental knowledge on attitude towards reusable bag.

As a construct that represents feelings and responsibilities in doing an action, the moral norm has been pretty much researched and proven to have an effect on attitudes related to pro environmental behaviours such as consuming green products and recycling (Botetzagias et al., 2015; Chan \& Brian Bishop, 2013; Liu et al., 2020; Poškus, 2015). Moral norm itself is often interpreted as values that have been accepted in society and taken into consideration by individuals in decision making. Conner \& Armitage (1998) have proposed incorporating moral norms into the Theory-of-Planned Behavior in addition to the subjective norm, taking into account the occasional person's use of his or her morals before making a decision. In a meta-analysis, A.Klöckner (2013) incorporated personal norms in the model to predict the intention of behaving environmentally and proven these personal norms as an antecedent of attitude to environmentally caring behaviour. 
H3: there is a positive moral influence on attitude towards reusable bag.

Lifestyle of Health and Sustainability (LOHAS) describes people's tendencies about health and sustainability. According to Cheng et al. (2019) LOHAS is a segment of consumers who care about fitness, health, environment, selfdevelopment, sustainable living and social justice. People with LOHAS characteristics in themselves tend to choose environmentally friendly products and services as evidenced by Cheng et al. (2019) and Matharu et al. (2021). Research conducted by Pícha \& Navrátil (2019) identified segments of consumers who practice LOHAS and found that they had a positive attitude towards sustainable consumption. The use of LOHAS as a determinant of sustainable consumption is still relatively rarely studied, so it becomes an opportunity in this study to include it in the model.

H4: there is a positive influence of LOHAS on attitude towards reusable bag.

Attitude and behavioural intention are part of Theory-of-Planned Behavior with attitude as the most frequently researched construct. Attitude is the view of a person limited to an object as a result of his assessment of the object, while behavioural intention is the tendency of the person to act. Related to pro environmental behaviour, it has been proven that attitude has a positive effect on the consumption of green products (Jan et al., 2019; Liu et al., 2020; Mohd Suki, 2016).

$\mathrm{H} 5$ : there is a positive influence of attitude on behavioural intention

\section{METHOD}

The design of this study consists of several elements that are discussed below. Firstly, the research strategy which is a survey using self-administered questionnaire. Next, the unit of analysis of this search is the individual and lastly, this is a crosssectional study in which data are gathered just once (Sekaran \& Bougie, 2016). The data was collected using a purposive sampling method. In total, 300 people that have knowledge and understanding the usefulness of reusable bag completed the questionnaires. This study uses five variables adapted from previous researchers, namely Social Influence (Varshneya et al., 2017), Environmental Knowledge (Fawehinmi et al., 2020), Moral Norm (Liu et al., 2020), Attitude (Varshneya et al., 2017), Lifestyle of Health and Sustainability (Matharu et al., 2021) and Behavior intention (Lao, 2014; Teng \& Wang, 2015).

The data was analyzed using Structural Equation Modelling (SEM) with the help of AMOS version 23 and SPSS version 21. A confirmatory factor analysis (CFA) was performed to assess the scale items' validity and the Cronbach Alpha coefficient was used to evaluate the reliability. Table 1 below shows the results of validity and reliability tests. All of the factor loadings of CFA-based model were above 0.4 and valid (Jr. et al., 2014). Also, all the Cronbach Alpha Coefficients were above 0.6 that represent the internal consistency of the items (Jr. et al., 2014). Furthermore, goodnessof-fit testing was conducted to find out if the research model could be used, with the test results showing marginally fit models that can be seen from the following 
indicators: RMSEA: 0.91, IFI: 0.935, TLI: 0.928, NFI: 0.911, RFI: 0.901. Furthermore, the data were analyzed using structural equation modelling with the support of AMOS software version 23 and SPSS version 21.

Table 1. Validity and Reliability Result Tests

\begin{tabular}{|c|c|c|}
\hline Variable & $\begin{array}{l}\text { Factor } \\
\text { Loading }\end{array}$ & $\begin{array}{l}\text { Cronbach } \\
\text { Alpha }\end{array}$ \\
\hline Social Influence & & \multirow{4}{*}{0.922} \\
\hline 1. My friends, often recommended reusable bag to me. & 0.914 & \\
\hline $\begin{array}{l}\text { 2. My friends often go shopping using reusable bag with } \\
\text { me. }\end{array}$ & 0.908 & \\
\hline $\begin{array}{l}\text { 3. My friends often share their experiences and knowledge } \\
\text { about reusable bag with me. }\end{array}$ & 0.854 & \\
\hline \multicolumn{2}{|l|}{ Environmental Knowledge } & \multirow{4}{*}{0.931} \\
\hline $\begin{array}{l}\text { 1. I know about the problem of environmental pollution } \\
\text { caused by human activities. }\end{array}$ & 0,914 & \\
\hline 2. I have good knowledge about environmental issues. & 0,897 & \\
\hline $\begin{array}{l}\text { 3. I am aware of how to protect the environment from the } \\
\text { information from media. }\end{array}$ & 0,906 & \\
\hline \multicolumn{2}{|l|}{ Moral Norm } & \multirow{5}{*}{0.976} \\
\hline $\begin{array}{l}\text { 1. Buying reusable bags is my responsibility and } \\
\text { obligation towards other people and/or the } \\
\text { environment. }\end{array}$ & 0.929 & \\
\hline $\begin{array}{l}\text { 2. Buying reusable bags instead of conventional ones } \\
\text { would feel like making a personal contribution to } \\
\text { something better. }\end{array}$ & 0.962 & \\
\hline $\begin{array}{l}\text { 3. Buying reusable bags instead of conventional ones } \\
\text { would feel like the morally right thing. }\end{array}$ & 0.975 & \\
\hline $\begin{array}{l}\text { 4. Buying green products instead of conventional ones } \\
\text { would make me feel like a better person. }\end{array}$ & 0.954 & \\
\hline \multicolumn{2}{|l|}{$\begin{array}{l}\text { Behavioral Intention I would consider buying and using a } \\
\text { reusable bag because it doesn't have a negative impact on the } \\
\text { environment. }\end{array}$} & \multirow{6}{*}{0.971} \\
\hline $\begin{array}{l}\text { 1. If Reusable Bag is available at retailer/retail } \\
\text { (Supermarket and Hypermarket, I will buy it. }\end{array}$ & 0.906 & \\
\hline $\begin{array}{l}\text { 2. I am willing to buy Reusable Bag even though it is } \\
\text { expensive (compared to ordinary plastic bags). }\end{array}$ & 0.938 & \\
\hline $\begin{array}{l}\text { 3. I would like to gather information about reusable bags } \\
\text { and learn about them. }\end{array}$ & 0.890 & \\
\hline $\begin{array}{l}\text { 4. I want to recommend a reusable bag to my friends so } \\
\text { they will buy it. }\end{array}$ & 0.860 & \\
\hline $\begin{array}{l}\text { 5. I would like to recommend a reusable bag to my family } \\
\text { so they will buy it. }\end{array}$ & 0.930 & \\
\hline
\end{tabular}


Lifestyle of Health and Sustainability

1. I care about maintaining excellent physical health.

0.903

2. I care about protecting the environment.

3. I care about sustainable agriculture practices.

4. I care about using renewable energy sources.

5. I tell family and friends about the benefits of purchasing environmentally friendly products.

6. I care about women's issues.

7. I care about social consciousness.

8. I prefer to buy products from companies whose values are like mine.

9. I like choosing environmentally friendly products and services.

10 . I'm willing to pay $20 \%$ more for environmentally friendly products

Attitude (adapted from $\mathrm{Wu} \&$ Chen (2014)

1. I think practicing green consumption by using reusable bag is valuable.

2. I think practicing green consumption by using reusable bag is delightful.

3. I think practicing green consumption by using reusable bag is wise.

Source: Processed Data

\section{RESULTS AND DISCUSSION}

Descriptive statistics showed that the average respondent obtained an overview of the reusable bag from those nearby (mean: 3.2789). In addition, respondents are also aware of environmental issues and aware that the environment needs to be protected (mean: 3. 6555) and feel that the use of reusable bags makes them feel better, act morally properly responsible for environmental sustainability (mean: 3.8550). In addition, respondents also practice LOHAS, such as maintaining body fitness, protecting the environment, also willing to pay more for environmentally friendly products (mean: 3.7440). Similarly, according to respondents, using a reusable bag is a wise and valuable decision (mean: 3.8596).

Table 2 Hypothesis Tests Result

\begin{tabular}{|l|c|c|c|}
\hline Hypothesis & @ value & Estimate & Decision \\
\hline $\begin{array}{l}\text { H1: there is a positive Influence of social } \\
\text { influence on attitude towards reusable bag }\end{array}$ & 0.166 & -0.45 & Not supported \\
\hline $\begin{array}{l}\text { H2: there is a positive Influence of } \\
\text { environmental knowledge on attitude } \\
\text { towards reusable bag }\end{array}$ & 0.024 & 0.122 & Supported \\
\hline
\end{tabular}




\begin{tabular}{|l|c|c|c|}
\hline $\begin{array}{l}\text { H3: there is a positive Influence of moral } \\
\text { norm on attitude towards reusable bag }\end{array}$ & 0.000 & 0.772 & Supported \\
\hline $\begin{array}{l}\text { H4: there is a positive Influence of LOHAS } \\
\text { on attitude towards reusable bag }\end{array}$ & 0.005 & 0.233 & Supported \\
\hline $\begin{array}{l}\text { H5: there is a positive Influence of attitude } \\
\text { towards reusable bag on behavioural } \\
\text { intention using reusable bag }\end{array}$ & 0.000 & 0.882 & Supported \\
\hline
\end{tabular}

Source: Processed Data

This study aims to investigate factors that form attitude of pro-environmental behavior and its consequences. Out of the five hypotheses, four were found to be supported. As shown in Table 2, the effect of social influence on attitude towards reusable bag was not significant. It means that even if someone gets advice from the surrounding people about reusable bags, it does not encourage them to have a positive attitude towards reusable bags. This result is similar with the research by Varshneya et al. (2017) in the context of clothing made from organic materials. Thoegersen \& Zhou (2012) also found no social influence on organic food purchasing decisions and they argued that people in emerging countries such products are relatively new and rarely used by consumers. In Indonesia, reusable bag is a new phenomenon that still in its early stages and has not become a social norm for the society. Reusable bag is not consumed by the public at large and those who use it do not need anyone else's advice. Although people already understand the function of reusable bag, their evaluation of reusable bag is still heavily influenced by their personal norms and not derived from social norms or the influence of others.

The second hypothesis proves that the more consumers understand that environmental damage is caused by human activity and they know about various environmental damage, they will rate positively reusable bag and feel wise if using them. This finding is in line with the results of Fawehinmi et al. (2020). On the other hand, the results of the third hypothetical test show that if a person feels that using a reusable bag makes him responsible and contributes to the environment, then he considers the use of the reusable bag is a wise and meaningful decision. Similar findings by Liu et al. (2020) also mentioned that moral norms influences people's decision to practice green consumption.

The results of the fourth hypothesis test show people's concern for a healthy lifestyle, environmental sustainability, the purchase of environmentally friendly products and other aspects related to sustainability make them have a favourable attitude towards reusable bags. The findings of this study support research from Matharu et al. (2021) as well as Pícha \& Navrátil (2019). Similarly, the more positive one's attitude towards reusable bags, the intention is to use reusable bags increased which proves that the fifth hypothesis is supported. 


\section{E. CONCLUSION}

This study tries to integrate internal and external antecedents that can form attitudes towards reusable bags and their consequences to behavioural intentions. Out of the four antecedents proposed, only one antecedent has no positive effect on attitude, namely social influence which is an external factor. This means people's attitude to the use of reusable bags is not influenced by the opinions of others. Furthermore, other antecedents, namely moral norm, environmental knowledge and lifestyle of health and sustainability (LOHAS) proved to have a positive effect on attitude towards the reusable bag.

The results of this study can provide input for the government, retailers and other parties who want to campaign for the use of reusable bags whose ultimate goal is to achieve sustainable consumption. The results of this study contribute to the design of marketing communication strategies aimed at changing people's behaviour. Campaigns using reusable bags should feature ad scenarios that feature antecedents that are proven to form a positive attitude towards reusable bags. These social ads can be displayed on social media as well as conventional media and in-store communication.

To campaign for reusable bags on social media, it is necessary to consider using informational and transformational appeals. Informational appeal accentuates the utilitarian aspect, namely the usefulness of a product. While transformational appeal will show the emotional aspects that consumers feel when using certain products. Cadet et al. (2017) conducted research using both advertising appeals on social media and found that informational appeal can encourage consumers to be positive about the advertised product. This finding can be used for social message designers related to the use of reusable bags by displaying the benefits of reusable bags for both consumers and the environment.

Advertisements can show environmental damage caused by human consumption activities such as plastic waste, one of which is caused by plastic bags used by shopping. In addition, advertisements can also show consumers' statements that they feel responsible for environmental sustainability and morally they feel better while using reusable bag.

The social marketing campaigns can use a variety of advertising scenarios that reflect LOHAS, such as the use of environmentally friendly products and through instore communication that reflects the value embraced by retailers, which is sustainability. Value becomes important because the majority of the respondents in this study show that they like retailers that have similar value, which is supporting pro-environmental behaviour. Retailers should not provide plastic bags anymore, instead they have to put reusable bags in the store area and design the social marketing campaign using in-store communication like TV screen, banner messages placed on shelves.

Other theoretical implication of this study is corroborating the results of previous studies that in collectivist countries such as Indonesia, the desire to conduct pro environmental behaviour is more driven by moral internalization in itself than the 
influence of others. This shows that the urge to do the right thing comes from its moral obligation rather than following social norms (Liu et al., 2020). Previously Bamberg \& Möser (2007) have suggested that personal norms can even encourage people to engage in pro-environmental behaviour.

There are two major limitations in this study. The first pertains to the use of Indonesian consumers only as the respondents. The next study can conduct a crosscultural study to demonstrate cultural differences in the use of reusable bag since culture strongly influences some behaviours.

The second limitation is the scope of the research. Therefore future studies need to test the research model with other pro-environmental behaviour, such as recycling or buying green product, these two are also new to Indonesian people.

\section{REFERENCES}

1. A. Klöckner, C. (2013). A comprehensive model of the psychology of environmental behaviour-A meta-analysis. Global Environmental Change, 23(5), 1028-1038. https://doi.org/10.1016/j.gloenvcha.2013.05.014

2. Ajzen, I. (1991). The theory of planned behavior. Organizational Behavior and Human Decision Processes, 50(2), 179-211. https://doi.org/10.1016/0749-5978(91)90020-T

3. Akenji, L., Bengtsson, M., Briggs, E., Chiu, A., Daconto, G., Fadeeva, Z., Fotiou, S., Gandhi, R., Mathews, C., Salem, G. M. B. M. J., Sang-Arun, J., Srisakulchairak, T., Schandl, H., \& Tabucanon, M. (2015). Sustainable Consumption and Production A Handbook for Policymakers. In E. Briggs (Ed.), World Environment Day 2015 Copyright. United Nations Environment Programme. https://doi.org/10.29302/oeconomica.2008.10.2.23

4. Bamberg, S., \& Möser, G. (2007). Twenty years after Hines, Hungerford, and Tomera: A new meta-analysis of psycho-social determinants of pro-environmental behaviour. Journal of Environmental Psychology, 27(1), 14-25. https://doi.org/10.1016/j.jenvp.2006.12.002

5. Botetzagias, I., Dima, A.-F., \& Malesios, C. (2015). Extending the theory of planned behavior in the context of recycling: the role of moral norms and of demographic predictors. Resources, Conservation and Recycling, 95, 58-67. https://doi.org/10.1016/j.resconrec.2014.12.004

6. Burchett, J. H. (2015). Environmental Literacy and its Implications for Effective Public Policy Formation [The University of Tennessee Knoxville]. http://trace.tennessee.edu/utk_bakerschol/27

7. Cadet, F. T., Aaltonen, P. G., \& Kavota, V. (2017). The Advertisement Value of Transformational \& Informational Appeal On Company Facebook Pages. The Marketing Management Journal, 27(2), 116-130.

8. Chan, L., \& Brian Bishop. (2013). A moral basis for recycling: extending the theory of planned behaviour. Journal of Environmental Psychology, 36, 96-102. https://doi.org/10.1016/j.jenvp.2013.07.010

9. Chang, H. J., \& Watchravesringkan, K. (Tu). (2018). Who are sustainably minded apparel shoppers? An investigation to the influencing factors of sustainable 
apparel consumption. International Journal of Retail and Distribution Management, 46(2), 148-162. https://doi.org/10.1108/IJRDM-10-2016-0176

10. Chang, S. H., \& Chou, C. H. (2018). Consumer intention toward bringing your own shopping bags in Taiwan: An application of ethics perspective and theory of planned behavior. Sustainability (Switzerland), 10(6), 1-14. https://doi.org/10.3390/su10061815

11. Chen-Yu, J. H., \& Seock, Y. K. (2002). Adolescents' clothing purchase motivations, information sources, and store selection criteria: A comparison of male/female and impulse/nonimpulse shoppers. Family and Consumer Sciences Research Journal, 31(1), 50-77. https://doi.org/10.1177/1077727X02031001003

12. Cheng, C. C., Chang, Y. Y., Tsai, M. C., Chen, C. T., \& Tseng, Y. C. (2019). An evaluation instrument and strategy implications of service attributes in LOHAS restaurants. International Journal of Contemporary Hospitality Management, 31(1), 194-216. https://doi.org/10.1108/IJCHM-06-2017-0361

13. Conner, M., \& Armitage, C. J. (1998). Extending the Theory of Planned Behavior: A Review and Avenues for Further Research. Journal of Applied Social Psychology, 28(15), 1429-1464.

14. Costa, S., Zepeda, L., \& Sirieix, L. (2014). Exploring the social value of organic food: a qualitative study in France. International Journal of Consumer Studies, 38(3), 228237. https://doi.org/10.1111/ijcs.12100

15. Fawehinmi, O., Yusliza, M. Y., Mohamad, Z., Faezah, J. N., \& Muhammad, Z. (2020). Assessing the green behaviour of academics: The role of green human resource management and environmental knowledge. International Journal of Manpower, 41(7), 879-900. https://doi.org/10.1108/IJM-07-2019-0347

16. Geller, E. S. (1989). Applied Behavior Analysis and Social Marketing: An Integration for Environmental Preservation. Journal of Social Issues, 45(1), 17-36.

17. Hameed, I., Waris, I., \& Haq, M. A. ul. (2019). Predicting eco-conscious consumer behavior using theory of planned behavior in Pakistan. Environmental Science and Pollution Research, 26, 15535-15547. http://doi.org/10.1007/s11356-019-04967-9

18. Han, H., Moon, H., \& Hyun, S. S. (2020). Uncovering the determinants of proenvironmental consumption for green hotels and green restaurants: A mixedmethod approach. International Journal of Contemporary Hospitality Management, 32(4), 1581-1603. https://doi.org/10.1108/IJCHM-04-2019-0354

19. Jambeck, J. R., Geyer, R., Wilcox, C., Siegler, T. R., Perryman, M., Andrady, A. R. N., \& Law, K. L. (2015). Marine pollution. Plastic waste inputs from land into the ocean. Science, 347(6223), 768-771.

20. Jan, I. U., Ji, S., \& Yeo, C. (2019). Values and green product purchase behavior: The moderating effects of the role of government and media exposure. Sustainability, 11(6642), 1-16. https://doi.org/10.3390/su11236642

21. Jr., J. F. H., Black, W. C., Babin, B. J., \& Anderson, R. E. (2014). Multivariate Data Analysis. In Pearson Education Limited (Seventh Ed). Pearson Education Limited. https://doi.org/10.4324/9781351269360 
22. Lao, K. (2014). Research on mechanism of consumer innovativeness influencing green consumption behavior. Nankai Business Review International, 5(2), 211-224. https://doi.org/10.1108/NBRI-11-2013-0041

23. Levy, B. L. M., \& Marans, R. W. (2012). Towards a campus culture of environmental sustainability: Recommendations for a large university. International Journal of Sustainability in Higher Education, 13(4), 365-377. https://doi.org/10.1108/14676371211262317

24. Liu, M. T., Liu, Y., \& Mo, Z. (2020). Moral norm is the key: An extension of the theory of planned behaviour (TPB) on Chinese consumers' green purchase intention. Asia Pacific Journal of Marketing and Logistics, 32(8), 1823-1841. https://doi.org/10.1108/APJML-05-2019-0285

25. Martin, D. M., \& Väistö, T. (2016). Reducing the Attitude-Behavior Gap in Sustainable Consumption: A Theoretical Proposition and the American Electric Vehicle Market. Marketing in and for a Sustainable Society, 13, 193-213. https://doi.org/10.1108/S1548-643520160000013016

26. Matharu, M., Jain, R., \& Kamboj, S. (2021). Understanding the impact of lifestyle on sustainable consumption behavior: a sharing economy perspective. Management of Environmental Quality: An International Journal, 32(1), 20-40. https://doi.org/10.1108/MEQ-02-2020-0036

27. McKenzie-Mohr, D. (2000). New Ways to Promote Proenvironmental Behavior: Promoting Sustainable Behavior: An Introduction to Community-Based Social Marketing. Journal of Social Issues, 56(3), 543-554. https://doi.org/10.1111/00224537.00183

28. Mohd Suki, N. (2016). Green product purchase intention: impact of green brands, attitude, and knowledge. British Food Journal, 118(12), 2893-2910. https://doi.org/10.1108/BFJ-06-2016-0295

29. Nation, U. (2017). The Sustainable Development Goals Report 2017. In United Nations.

30. Peattie, K., \& Peattie, S. (2009). Social marketing: A pathway to consumption reduction? Journal of Business Research, 62(2), 265-268. https://www.sciencedirect.com/science/article/abs/pii/S0148296308000489

31. Pícha, K., \& Navrátil, J. (2019). The factors of Lifestyle of Health and Sustainability influencing pro-environmental buying behaviour. Journal of Cleaner Production, 234, 233-241. https://doi.org/10.1016/j.jclepro.2019.06.072

32. Poškus, M. S. (2015). Predicting Recycling Behavior by Including Moral Norms Into The Theory of Planned Behavior. Psichologija, 52, 22-32. https://doi.org/10.15388/psichol.2015.52.9330

33. Salazar, H. A., Oerlemans, L., \& Van Stroe-Biezen, S. (2013). Social influence on sustainable consumption: Evidence from a behavioural experiment. International Journal of Consumer Studies, 37(2), 172-180. https://doi.org/10.1111/j.14706431.2012.01110.x

34. Saunders, S. G., Barrington, D. J., \& Sridharan, S. (2015). Redefining social marketing: Beyond behavioural change. Journal of Social Marketing, 5(2), 160-168. 
https://doi.org/10.1108/JSOCM-03-2014-0021

35. Sekaran, U., \& Bougie, R. (2016). Research Methods for Business. www.wileypluslearningspace.com

36. Singhal, A., \& Malik, G. (2018). The attitude and purchasing of female consumers towards green marketing related to cosmetic industry. Journal of Science and Technology Policy Management. https://doi.org/10.1108/JSTPM-11-2017-0063

37. Stern, P. C. (2000). Toward a coherent theory of environmentally significant behavior. Journal of Social Issues, 56(3), 407-424. https://doi.org/10.1111/00224537.00175

38. Teng, C. C., \& Wang, Y. M. (2015). Decisional factors driving organic food consumption: Generation of consumer purchase intentions. British Food Journal, 117(3), 1066-1081. https://doi.org/10.1108/BFJ-12-2013-0361

39. Thoegersen, J., \& Zhou, Y. (2012). Chinese Consumers' Adoption of a "green" innovation. - The case of organic food. Journal of Marketing Management, 28(3-4), 313-333. http://doi.org/10.1080/0267257X.2012.658834

40. Varshneya, G., Pandey, S. K., \& Das, G. (2017). Impact of Social Influence and Green Consumption Values on Purchase Intention of Organic Clothing: A Study on Collectivist Developing Economy. Global Business Review, 18(2), 478-492.

41. Wei, Z., Zhao, Z., \& Zheng, Y. (2019). Following the Majority: Social Influence in Trusting Behavior. Zhenyu Wei 1 2, Zhiying Zhao 1, Yong Zheng 2, 13(89). https://doi.org/10.3389/fnins.2019.00089

42. Wu, S.-I., \& Chen, Y.-J. (2014). The Impact of Green Marketing and Perceived Innovation on Purchase Intention for Green Products. International Journal of Marketing Studies, 6(5), 81-100. https://doi.org/10.5539/ijms.v6n5p81 